\title{
Determinants of Environmental Quality in Nigeria: Assessing the Role of Financial Development
}

\author{
Ekundayo P. Mesagan** and Mike I. Nwachukwu* \\ ^Department of Economics, University of Lagos, Nigeria
}

Submitted: April 2, 2018 • Accepted: July 11, 2018

\begin{abstract}
In this study, we analyze the determinants of environmental quality in Nigeria, focusing on the role of financial development. It is a time series analysis covering the period from 1981 to 2016. The study uses the ARDL bounds testing approach to analyze data on urbanization, per capita income, environmental degradation, energy consumption, trade intensity, and capital investment. We generate the environmental degradation index using principal component analysis (PCA). Empirical results suggest that income, financial development, energy consumption, and trade are significant in explaining environmental quality, whereas investment and urbanization are insignificant in the model. Moreover, we find no causality between the capital investment, financial development, and environmental quality, although urbanization and income unidirectionally cause environmental degradation. Also, there exists a bidirectional causality between energy consumption and environmental degradation. Therefore, to ensure efficient credit allocation to low carbon emitting firms, financial sector operators should adequately screen investment proposals before committing funds to them.
\end{abstract}

JEL classification: O16, O44, Q43

Keywords: financial development, energy, income, environment, Nigeria

${ }^{*}$ Corresponding Author. Email: profdayoms@yahoo.com 


\section{Introduction}

Without a doubt, the financial sector plays a significant role in mobilizing and using savings, in facilitating business transactions, and in monitoring resources for economic advancement (Nasreen et al., 2017). It plays a vital role in the growth and development of the economy because when efforts are made to develop the financial sector properly, it promotes effective mobilization and allocation of economic and financial resources (Adekunle et al., 2013). A study by Aderibigbe (2001) affirms that Nigeria's financial sector assists in facilitating the necessary business transactions for economic development. One can, therefore, agree that an efficient financial sector will increase investment activities (by issuing low-interest loans), allocate resources toward productive channels, facilitate trade activities, manage risks, effectively monitor firms' activities, and encourage firms to use environmentally friendly production techniques in their operations.

Dasgupta et al. (2001) opined that countries with more stable financial markets would, in most cases, enjoy a cleaner environment than countries with less developed financial markets. Also, the empirical literature suggests that foreign direct investment is encouraged in countries that have stable financial markets, in a quest to promote growth, and this has implications for the environment. Thus, there appears a relatively clear relationship between financial sector development and environmental quality, as there are several channels through which the financial sector impacts the environment. For instance, improvement in financial activities can spur economic growth, which has implications for environmental quality, as suggested by the environmental Kuznets curve (EKC). Again, financial sector improvement can impact the environment by encouraging the private sector to increase investments in new technologies. This investment expansion boosts the volume of industrial energy consumption, which can either increase or decrease emissions of carbon depending on the energy mix (Mesagan et al., 2018). Also, the level of a country's financial development strongly determines the allocation of credit to investments that can enhance or reduce environmental quality. The reason is that high carbon emitting firms can be denied credit facilities by financial institutions, making funds available only to firms that will emit less carbon. It is therefore apparent that financial sector development can play a crucial role, through various channels, in determining the environmental quality of a nation. Hence, the authors of a number of empirical studies have concluded that financial performance is essential in stimulating activity related to promoting or protecting environmental quality (Charfeddine and Khediri, 2016; Maji et al., 2017; Mahalik et al., 2017; Shahbaz et al., 2017; Salahuddin et al., 2018).

Regarding theoretical expositions, the EKC implies that at the early developmental stage of an economy, growth is achieved by increases in the volume of emissions. Then, as the economy becomes financially stable, it is able to achieve green growth (Andreoni and Levinson, 2001; Dasgupta et al., 2001). This is because the country can control its emissions even as 
growth continues to rise. The EKC implies that there is an inverted U-shaped relationship between economic growth and environmental pollution (Dasgupta et al., 2001). Interestingly, since the quality of financial services being offered in a country provides an essential stimulant to economic growth (Levine, 1996), it becomes crucial for every nation to ensure that its financial sector plays an active role in promoting green growth. Therefore, in-depth knowledge of the role of financial sector development in promoting environmental quality is critical because it enables a country to improve its financial services and attract foreign investment to boost green growth. Thus, increasing environmental efficiency through financial system improvement occupies the heart of this scientific enquiry. According to Sadorsky (2011), financial development has implications for energy demand, as well as determining energy conservation and carbon emissions policies. In such circumstances, to better understand energy demand dynamics for effective management of carbon dioxide $\left(\mathrm{CO}_{2}\right)$ emissions, Karanfil (2009) proposes augmenting the energy demand function with critical financial indicators beyond just income variables. This means that there are active links between energy use, financial resources, and quality of the environment.

For Nigeria, World Bank data suggest that between 1981 and 2014, $\mathrm{CO}_{2}$ emissions rose by about $41.3 \%$ (i.e., from 65,958.33 kilotonnes (kt) to 96,280.75 kt). The Federal Environmental Protection Agency was established in 1992 to curtail increases in $\mathrm{CO}_{2}$ in the country (World Development Indicators, 2017). Regarding the development of the financial sector in Nigeria, the credit available to the private sector rose from $\$ 8.57$ billion in 1981 to $\$ 21,082$ billion in 2016. This calls into question whether there is any linkage between the volume of investment generated by the amount of credit made available to the private sector and the size of $\mathrm{CO}_{2}$ emissions in a country (Central Bank of Nigeria, 2017). Finally, energy consumption per capita increased from $676.38 \mathrm{~kg}$ of oil equivalent in 1981 to $763.39 \mathrm{~kg}$ in 2014 (World Development Indicators, 2017), while the real gross domestic product (GDP) also rose significantly from $\mathrm{N} 15,258$ billion in 1981 to $\$ 67,931$ billion in 2016 (Central Bank of Nigeria, 2017). Hence, it seems evident that both energy use and the real GDP are essential drivers of $\mathrm{CO}_{2}$ emissions in Nigeria as several empirical studies have posited (Mesagan, 2015; Shahbaz et al., 2014; Eregha and Mesagan, 2017).

Despite the number of environmental laws that have been put forward to protect the environment from degradation, oil spillage, and gas flaring in Nigeria, the degradation is still the case. For instance, the Department of Petroleum Resources noted that Nigeria recorded a total of 2,097 oil spills between 1997 and 2001 (Nwilo and Badejo, 2006). Nigeria is the focus of this study because it is the largest African economy in terms of population and output, and it depends significantly on fossil fuels for generating its electricity. The country is Africa's largest producer of crude oil and records the highest amount of gas flaring in Africa. Indeed, by the end of December 2015, Nigeria ranked 6th globally behind only Russia, Iraq, Iran, 
the United States, and Venezuela, with gas flaring of 8 billion cubic meters (bcm) (World Bank, 2016). It is thus pertinent to focus on Nigeria because of its size and for the fact that it can provide a template for other African countries to follow in the quest to improve environmental quality on the continent. Based on the preceding, it becomes vital to examine the determinants of environmental quality in Nigeria. Specifically, this study analyzes the impact of financial sector development on environmental degradation, investigates the causal nexus between the environment and its determinants, and tests the proposition of the EKC in Nigeria. The study is topical for Nigeria because of the need for the financial sector to play an active role in $\mathrm{CO}_{2}$ emissions abatement efforts in order to complement the activities of other government agencies in improving environmental quality. The paper is organized in the following manner: section 1 provides the literature review; section 2 presents the research methodology; section 3 presents the empirical results; and section 4 presents the conclusion and policy recommendations.

\section{Literature Review}

In this section, we examine the scholarly articles in the literature to give clear direction to the purpose and understanding of the contribution of this study. To this end, we review previous country-specific and cross-country studies. A number of country-specific studies have been published that examined relevant questions in the context of a single country. Moghadam and Dehbashi (2018) analyzed the impact of financial development and trade on Iran's environmental quality and found that financial growth worsened environmental degradation, whereas trade was seen to reduce environmental damage. Similarly, Boutabba (2014) examined the nexus between financial development, income, energy use, trade, and carbon emissions and confirmed the EKC hypothesis for the Indian economy. The study also found a unidirectional causality running from income, energy consumption, and financial development to $\mathrm{CO}_{2}$ emissions. Charfeddine et al. (2018) examined the link between economic growth and the environment in Qatar. This study, which employed the ARDL bounds testing approach, found support for the EKC hypothesis. The authors, therefore, suggested energy conservation policies to lower the adverse effects of growth on the environment. Jalil and Feridun (2011) established that financial development decreased environmental pollution in China, and also confirmed the existence of the EKC for the country. Similarly, Shahbaz et al. (2013) also proved that financial development and trade openness lowered $\mathrm{CO}_{2}$ emissions, whereas economic growth raised $\mathrm{CO}_{2}$ emissions in South Africa. Alam et al. (2015) analyzed Malaysia and found that carbon emissions had a positive correlation with broad money supply and domestic credit to the private sector. They also found that energy demand positively and significantly enhanced financial sector credit, but negatively affected 
the broad money supply. Maji et al. (2017) conducted a sectoral analysis and found that financial development intensified $\mathrm{CO}_{2}$ emissions in both the transportation and oil and gas sectors, whereas it reduced $\mathrm{CO}_{2}$ emissions in the manufacturing and construction sectors in Malaysia. Charfeddine and Khediri (2016) focused on the United Arab Emirates (UAE) using cointegration with structural breaks. The study found an inverted U-shaped relationship between financial development and $\mathrm{CO}_{2}$ emissions. However, it observed that electricity consumption, trade openness, and urbanization improved environmental quality in the UAE. Javid and Sharif (2016) confirmed the EKC in Pakistan in the short and long runs, and also traced the low environmental quality in the country to the weak financial institutions and the level of energy consumption. Alege and Ogundipe (2015) focused on the Nigerian economy and found that income had a positive and linear relationship with $\mathrm{CO}_{2}$ emissions. Also, the study established a positive correlation between foreign direct investment, trade openness, and $\mathrm{CO}_{2}$ emissions in the country. However, the research did not support the existence of the EKC in Nigeria. Ozturk and Acaravci (2013) analyzed the Turkish economy and found a long-term relationship between $\mathrm{CO}_{2}$ emission, energy consumption, real income, trade, and financial development. However, it found that financial development did not significantly affect the Turkish environment. Shahbaz et al. (2017) showed that, in India, no causality exists between energy consumption and financial development, whereas financial development and energy consumption negatively affected income growth.

Concerning cross-country studies, Khan et al. (2018) discussed income inequality for Asian economies and established that a significant negative relationship exists between financial development and carbon emissions. It also found that greater income inequality reduced carbon emissions, whereas increased energy use significantly worsened carbon emissions in the Asian region. Kahouli (2017) examined short-run and long-run causality between growth, energy use, and financial development in six southern Mediterranean countries. The study observed the existence of a long-run relationship between the variables, and also confirmed the presence of a short-run causal relationship in five of the countries examined. Abid (2017) established a monotonically increasing link between carbon emissions and economic growth in the Middle East, Africa, and the European Union countries between 1990 and 2011. Almulali et al. (2013) focused on urbanization, energy consumption, and $\mathrm{CO}_{2}$ emissions in the Middle East and North African (MENA) countries. Their study established long-run bidirectional positive relationships between the variables investigated. Bekhet et al. (2017) focused on the Gulf Cooperation Council (GCC) countries and established a long-run causal nexus between economic growth, financial development, and $\mathrm{CO}_{2}$ emissions. They also confirmed that financial development unidirectionally caused $\mathrm{CO}_{2}$ emissions in the UAE, Oman, and Kuwait. Al-mulali and Sab (2012) observed that energy consumption and financial development worsened environmental pollution in 19 selected countries, subsequently calling for 
reduced emissions in these countries through energy protection policies. Nasreen et al. (2017) studied Asian economies and found a negative effect of increased financial stability on carbon emissions, whereas higher energy consumption and economic growth increased $\mathrm{CO}_{2}$ emissions among the countries considered. For Omri et al. (2015), the study found a bidirectional causality between $\mathrm{CO}_{2}$ emissions and income, as well as between trade openness and financial development. It also found a unidirectional relationship running from financial development to income and carbon emissions in MENA countries. Saidi and Mbarek (2017) observed that financial development reduced environmental degradation in emerging economies.

Based on this review of previous studies, it is evident that scholars have identified financial development as an essential determinant of environmental quality. However, most of these studies have used $\mathrm{CO}_{2}$ emissions as the indicator of environmental quality, which might not be enough. Studies such as those by Frankel and Rose (2005) and Li et al. (2015) identified several proxies for environmental quality. The present study takes a cue from these latter studies, generating an environmental quality index from particulate emissions damage and $\mathrm{CO}_{2}$ emissions using principal component analysis (PCA). Using this environmental quality index, we differentiate this present study from the others and check if our result is different from other country-specific results about the finance-environment nexus. Also, the shortage of studies on the Nigerian economy regarding the critical role of financial development in the environment necessitates this present study.

\section{Research Methodology and Estimation Technique}

\section{$2.1 \quad$ Methodology}

To conduct this scientific enquiry, we adopt the EKC framework which suggests that there is an inverted U-shaped relationship between income and environmental pollution. Therefore, following Andreoni and Levinson (2001), Dasgupta et al. (2002), and Stern (2004), we specify the EKC model as follows:

$$
E_{t}=\varphi+\beta_{1} Y_{t}+\beta_{2} Y_{t}^{2}+\varepsilon_{t}
$$

In equation (1), $E$ is the environmental quality index computed from the PCA, $\varphi$ is the intercept term, $\beta_{1}$ and $\beta_{2}$ are the coefficients of income per capita of the first and second derivatives respectively, $\varepsilon$ is the residual term, and $t$ represents the time index. According to the EKC model formulated in equation (1), $\beta_{1}$ and $\beta_{2}$ are expected to have positive and negative signs, respectively, to confirm the EKC hypothesis in Nigeria. Notably, $E$ is computed 
from $\mathrm{CO}_{2}$ emissions and particulate emissions damage (PM) in Nigeria. To accommodate other determinants of environmental quality, we modify equation (1) as follows:

$$
E_{t}=\varphi+\beta_{1} Y_{t}+\beta_{2} Y_{t}^{2}+\beta_{3} F D_{t}+\beta_{4} E C_{t}+\beta_{5} I N V_{t}+\beta_{6} T I_{t}+\beta_{7} U B N_{t}+\varepsilon_{t}
$$

We include all the explanatory variables to be estimated in equation (2). In equation (2), $F D$ represents financial development and it is proxied by the available credit to the private sector. $E C$ is the amount of energy consumed; $I N V$ represents the volume of capital investment, proxied by the gross fixed capital formation; $T I$ is the trade intensity ratio, calculated as total trade divided by the GDP; and $U B N$ is the rate of urbanization. The remaining variables are as explained in equation (1).

\subsection{Estimation Technique}

To estimate the specified model, we use the autoregressive distributed lag (ARDL) bounds testing approach. According to Pesaran and Shin (1998) and Pesaran et al. (2001), the method is built on the Wald test or F-statistic to determine the implication of the lagged values of variables in a conditional and unrestricted dynamic error correction model. Also, we use the ARDL bounds test due to the need to determine the short- and long-run effects of the explanatory variables on environmental quality, and for its superiority over other estimation techniques when the study entails a small sample. Again, in this study, we use the standard t-test and F-test to determine the strength of the lagged variables in the first difference estimation. One significant advantage of this methodology is that the F-test and t-test are applicable whether the variables are $I(0), I(1)$ or integrated mutually. Hence, following Pesaran and Shin (1998), we estimate the following unrestricted error correction model:

$$
\Delta E_{t}=\alpha_{0}+\sum_{i=1}^{p} \alpha_{1} \Delta E_{t-i}+\sum_{i=1}^{p} \alpha_{2} \Delta V_{t-i}+\beta_{1} E_{t-1}+\beta_{2} V_{t-1}+\varepsilon_{t}
$$

Where $E$ is the dependent variable, $V$ stands for independent variables, $p$ is the lag structure, $\Delta$ is the difference operator, $\alpha_{1}$ and $\alpha_{2}$ are the short-run estimates, $\beta_{1}$ and $\beta_{2}$ are the long-run estimates, and $\varepsilon$ is the white noise error term. For the models to be estimated in this study, the hypothesis to be tested is:

$H_{0}: \beta_{1}=\beta_{2}=\ldots=\beta_{n}=0$ (i.e., there is no long-run relationship).

$H_{1}: \beta_{1} \neq \beta_{2} \neq \ldots=\beta_{n} \neq 0$ (i.e., there is a long-run relationship). 
Hence, using the F-test suggested in Pesaran and Shin (1998) and Pesaran et al. (2001), the estimated ARDL test statistics will be compared with the two asymptotic critical values in Pesaran et al. (2001) as against the conventional critical values. Therefore, if the estimated test statistic is higher than the upper critical value, we will reject the null hypothesis of no long-run relationship, but if it is lower than the lower critical value, we will accept the null hypothesis. However, if the estimated test statistic lies between the two critical values or bounds, then the result is inconclusive.

Thus, following Pesaran and Shin (1998) and Pesaran et al. (2001), the reduced form model to be estimated in this study is specified as:

$$
\begin{aligned}
\Delta E_{t} & =\alpha_{0}+\sum_{i=1}^{p} \alpha_{1} \Delta E_{t-i}+\sum_{i=1}^{p} \alpha_{2} \Delta Y_{t-i}+\sum_{i=1}^{p} \alpha_{3} \Delta Y_{t-i}^{2}+\sum_{i=1}^{p} \alpha_{4} \Delta F D_{t-i}+ \\
& +\sum_{i=1}^{p} \alpha_{5} \Delta T I_{t-i}+\sum_{i=1}^{p} \alpha_{6} \Delta E C_{t-i}+\sum_{i=1}^{p} \alpha_{7} \Delta I N V_{t-i}+\sum_{i=1}^{p} \alpha_{8} \Delta U B N_{t-i}+ \\
& +\beta_{1} E_{t-1}+\beta_{2} Y_{t-1}+\beta_{3} Y_{t-1}^{2}+\beta_{4} F D_{t-1}+\beta_{5} T I_{t-1}+\beta_{6} E C_{t-1}+ \\
& +\beta_{7} I N V_{t-1}+\beta_{8} U B N_{t-1}+\varepsilon_{t}
\end{aligned}
$$

Where $\Delta$ is the first difference operator, $\alpha_{0}$ represents the drift, $\alpha_{1-8}$ are the short-run dynamic coefficients of the underlying ARDL model, $\beta_{1-8}$ represents the long-run multipliers, $t$ is the time index, and $\varepsilon_{t}$ is the white noise error term. Also, $E$ is the vector of dependent variables, which represents the environmental degradation index, $\mathrm{CO}_{2}$ emissions, and particulate emissions damage; $Y$ is income per capita; $F D$ is financial development; $T I$ is trade intensity; $E C$ is energy consumption; and $U B N$ is the rate of urbanization.

We analyze the time series data covering a period from 1981 to 2016 . We extract data for particulate emissions, $\mathrm{CO}_{2}$ emissions, energy consumed, gross fixed capital formation, per capita income, and rate of urbanization from the World Bank's World Development Indicators (2017). We generate data on credit available to the private sector from the Central Bank of Nigeria Statistical Bulletin (Central Bank of Nigeria, 2017). In the model, variables such as $\mathrm{CO}_{2}$ emissions and particulate emissions are used to capture environmental quality, whereas the independent variables include financial sector development proxied by commercial banks' credit to the private sector, energy consumption, and trade intensity ratio. We also include urban population as a proxy for the urbanization rate and gross fixed capital formation as a proxy for investment. The theoretical justification for the inclusion of these variables is provided next. 


\subsection{Theoretical Justification for the Inclusion of Variables}

In this section, we analyze the choice of environmental determinants and provide theoretical justification for their inclusion in the model. For instance, carbon dioxide emission is the most widely used indicator of environmental degradation, as the level of environmental quality has often been related to the volume of $\mathrm{CO}_{2}$ emissions that is prevalent in a country. According to the EKC, pollution and income growth are inseparable twins: efforts to increase income often come with increases in pollution (Andreoni and Levinson, 2001). Therefore, income per capita is used as an explanatory variable in this study because of its relationship with $\mathrm{CO}_{2}$ emissions. Paul and Bhattacharya (2004) observed that income growth is the highest contributor to carbon emissions. Thus, while income per capita is used to test the rising portion of the EKC, income squared is used to test the falling part of the EKC in the model, and both are necessary to determine the inverted U-shaped curve of the EKC. We also include particulate emissions damage, the damage caused by exposing citizens to severe ozone pollution (World Development Indicators, 2017). We include energy consumption as it is an essential determinant of environmental pollution in a location. Empirical studies such as Soytas et al. (2007) and Mesagan et al. (2018) opined that energy consumption has severe implications for environmental quality because it is crucial in the production process. Again, when trade openness increases in a country, it enables the country to gain access to improved technology for pollution abatement; the country also gains access to international capital markets for the inflow of investment, which has environmental implications too (Copeland and Taylor, 1994). This informs why trade intensity ratio is brought into the model as a determinant of environmental quality. Assessing the critical role of financial development is germane to this study because a well-developed financial system can function to allocate credit to low-carbon emitting firms. Also, according to Solarin et al. (2017), the financial sector makes liquidity available to the real sector of the country and thereby contributes to the pollution level. Moreover, activities of an efficient financial intermediary provide the impetus for firms to obtain credit facilities to purchase automobiles used in production. Furthermore, when adequate financing is made available and new machines are acquired, energy consumption increases, and the pollution level expands as well. Other previous studies that have controlled for financial development as a determinant for environmental quality include Omri et al. (2015), Bekhet et al. (2017), Nasreen et al. (2017), Saidi and Mbarek (2017), and Shahbaz et al. (2017). This explains why financial development is used in this study. Investment and urbanization rate are used in this study because the pace of urbanization and the quality of investment are crucial indices of environmental quality. As noted by Sadorsky (2014), when urbanization increases, economic activities expand, and pollution increases too. Meanwhile, Mesagan et al. (2018) identified investment as an essential channel for improving environmental quality. 


\section{Empirical Results}

In Table 1, we present the descriptive statistics of variables used in the study. Between 1981 and 2016, the means of per capita income, energy consumption, investment, and urban population in Nigeria are US $\$ 1,583.22$, US $\$ 103.37,37.26 \%$, and $35.00 \%$ respectively. Also, the means of trade intensity ratio, particulate emissions damage, carbon emissions, and financial development in Nigeria are 50.41\%, 1.96\%, $0.59 \mathrm{kt}$, and $\mathrm{N} 15.09$ billion respectively.

Furthermore, regarding the maximum values, these are $\$ 2,634.36, \$ 156.73,35.22 \%$, and $48.59 \%$ for per capita income, energy consumption, investment, and urban population respectively, whereas their minimum values are $\$ 1,153.38, \$ 50.87,5.45 \%$, and $22.67 \%$ respectively. Also, the maximum amounts for trade intensity ratio, particulate emissions damage, carbon emissions, and financial development in Nigeria are 81.81\%, 2.24\%, $0.87 \mathrm{kt}$, and N38.39 billion respectively, whereas their minimum amounts are $21.12 \%, 1.30 \%, 0.33 \mathrm{kt}$, and $\mathrm{N} 8.71$ billion respectively during the study period.

Table 2 presents the matrix of correlations between the variables. The correlation matrix makes it possible to determine the level of association and the possibility of multicollinearity of the regressors. As presented in Table 2, the regressors used in the study are not correlated. Hence, the model formulated in this study is not affected by the multicollinearity problem.

Table 3 presents the result of the unit root test using the augmented Dickey-Fuller (ADF) test. The table shows the outcome of the stationarity test at both levels, the first difference at the trend level, and when there is no trend. In table 3, we observe that only financial development is stationary at levels while trade intensity ratio, real income, investment, particulate emissions, energy consumption, urbanization rate, and $\mathrm{CO}_{2}$ emissions are stationary at first difference. Because we have confirmed the stationarity of the series, we can then proceed to estimate the ARDL bounds test to determine if there is cointegration among the series and also analyze the short-run and long-run effects of the estimators on environmental quality.

For the three models, the hypothesis tested include:

$H_{0}: \beta_{1}=\beta_{2}=\ldots=\beta_{n}=0$ (i.e., there is no long-run relationship).

$H_{1}: \beta_{1} \neq \beta_{2} \neq \ldots=\beta_{n} \neq 0$ (i.e., there is a long-run relationship).

Table 4 presents the ARDL bounds test for determining the long-run relationship using the Akaike information criterion (AIC) to select the appropriate lag length. In selecting the critical bounds, we use the values specified in Pesaran et al. (2001) for the restricted intercept and no trend (i.e., case II). We test the hypothesis at the various significance levels with $\mathrm{F}$ statistics and with $k=7$ against the specified critical bounds. The ARDL bounds test results presented in Table 4 confirms that the F-statistics computed are higher than the critical 
values of the upper bound tests. Hence, we reject the null hypotheses of no cointegration across the three models at the $1 \%, 5 \%$, and $10 \%$ significance levels, and confirm that there is a unique and stable long-run relationship between environmental quality and financial sector development, together with other determinants in Nigeria between 1981 and 2016.

Because Table 4 has confirmed the existence of a stable and long-run relationship between the estimated regressors in the study, we present the results of the determined ARDL longrun coefficients in Table 5. In displaying the results in Table 5, we show the effect of the explanatory variables on environmental quality in model I. For the sake of conducting a sensitivity analysis, we also show the impact of the explanatory variables on $\mathrm{CO}_{2}$ emissions and particulate emissions in model II and model III. Models II and III, therefore, serve as robustness checks in this study.

A cursory look at Table 5 suggests that income positively and significantly impacts the environmental degradation index, $\mathrm{CO}_{2}$ emissions, and particulate emissions damage. The implication is that economic growth has often worsened environmental challenges facing the country. Therefore, the result is in line with Boutabba (2014) and Charfeddine et al. (2018), but at variance with Khan et al. (2018). The coefficient of financial sector development is positive and significant in worsening environmental degradation and $\mathrm{CO}_{2}$ emissions, but insignificant in contributing to particulate emissions in Nigeria. It thus implies that despite the efforts to improve the Nigeran financial sector, it has neither been able to allocate credits to investments that should improve environmental quality nor significantly reduce environmental degradation in the country. This result supports earlier findings that financial development worsened environmental degradation in the UAE, Oman, Kuwait (Bekhet et al., 2017) and Iran (Moghadam and Dehbashi, 2018).

However, the result is at variance with Shahbaz et al. (2013) and Nasreen et al. (2017), who found that financial stability improved environmental quality in South Africa and South Asian economies, respectively. Regarding energy consumption, our results show support for Javid and Sharif (2016), as energy consumption positively and significantly enhanced the indicators of environmental degradation in the study. This result also conforms to a priori expectation as the country generates most of its energy from fossil fuels which intuitively means that energy consumption is a major driver of environmental degradation in Nigeria as is indicated by the coefficient.

Moreover, empirical results in Table 5 suggest that trade intensity positively and significantly affects the environmental degradation index and carbon emissions, whereas it has a negative impact on particulate emissions. This means that the inflow and outflow of trade in Nigeria have a severe negative effect on its environmental degradation, a result in line with Alege and Ogundipe (2015), but at variance with the results of Shahbaz et al. (2013) and Charfeddine and Khediri (2016) for South Africa and the UAE, respectively. However, 
our results suggest that investment has a positive but insignificant impact on environmental degradation, whereas it has an adverse but significant effect on particulate emissions. This means that investment is not a significant determinant of environmental quality in Nigeria when we consider carbon emissions, but it has a substantial effect in lowering particulate emissions damage in the country. This result is at variance with Mesagan et al. (2018), who confirmed that capital investment is an essential channel for improving environmental quality in BRICS. Also, the coefficient of urbanization suggests that it positively but insignificantly affects environmental degradation and $\mathrm{CO}_{2}$ emissions, whereas it positively and significantly increases PM emissions in the study. This study attributes PM emissions to the waste disposal from urbanization and implies that urbanization is not a significant determinant of environmental pollution in Nigeria. Lastly, this research finds support for the existence of the EKC in Nigeria as the coefficient of the income-squared is negative for all environmental indicators in the model.

In Table 6, we present both the diagnostic test and stability test for the empirical models. The error correction terms (ECT) of $-1.782,-0.835$, and -0.639 imply that the three models converge in the long run. It also means that the adjustment speed is fast at $178.2 \%, 83.5 \%$, and $63.9 \%$ for the three models. Because the ECT terms are negative and significant at $5 \%$, this means that the ARDL models are well specified. The results give credence to the existence of a long-run relationship between environmental quality and its determinants in Nigeria.

The diagnostic tests indicate the models are well specified as they are free from serial correlation, are homoscedastic, and are multivariate normally distributed. The cumulative sum of squared and cumulative sum statistics are within the $5 \%$ critical levels, indicating stability of the models, while the functional form tests also show that the three models are well specified.

Regarding the determinants of environmental quality, a cursory look at Table 7 shows that no causal nexus exists between financial sector development and the environment or between trade intensity and the environment in Nigeria. This implies that there is no feedback effect between the financial sector, capital investment, and environmental quality in Nigeria. The result also confirms that there is a unidirectional causal nexus running from urbanization to the environment, and from income to environmental degradation. Intuitively, it means that an increase in the pace of urban growth and per capita income causes environmental degradation to rise because waste generated from urbanization and the continuous pressure on natural resources from the rising population causes depletion of the environment. Moreover, the fact that income unilaterally causes environmental degradation in the study gives credence to the EKC proposition, which suggests that income determines the pollution level. However, both energy consumption and environmental degradation are mutually causal, implying that there 
is a feedback effect between energy consumed and environmental degradation in Nigeria.

\section{Discussion of Results}

We observe that income exerts a positive and significant impact on the environmental degradation index, $\mathrm{CO}_{2}$ emissions, and particulate emissions damage, meaning that efforts to increase economic growth have often been made with less attention to curtailing environmental degradation. This is further supported by the continuous flaring of gas in Nigeria's Niger Delta region, in an attempt to earn foreign exchange without much consideration for the environmental effects or the effects on people's lives. As opined in Isola and Mesagan (2014), huge earnings from crude oil production without concern for the human condition is counter-productive to the nation. Though Boutabba (2014) and Charfeddine et al. (2018) found similar conclusions, the index generated for the environment in this study makes our findings different from that of Khan et al. (2018). Again, the financial sector significantly and positively worsens environmental degradation thereby negating the results of Shahbaz et al. (2013) and Nasreen et al. (2017). This means that the inability of these earlier studies to factor in particulate emissions might have resulted in their findings that financial development is associated with lower environmental pollution. Also, by factoring in PM emissions, this study confirms that although financial development increased particulate emissions, it was not significant in the particulate emissions model. This is attributable to the fact that the financial structure is not the primary determinant of particulate emissions in the country. Because the results of the analysis of energy consumption confirm the result of Javid and Sharif (2016) that higher energy consumption increases all the indicators of environmental degradation, this means that energy use continues to rise and environmental pollution also increases unabated. Because energy consumption is also significant, this implies that it is a critical determinant of environmental quality in Nigeria. Trade intensity was found to contribute significantly and positively in exacerbating the environmental degradation index and carbon emissions, but lowering particulate emissions. The implication is that trade is not only a significant determinant of environmental quality, but also an avenue to lower environmental degradation in the country through its effect on particulate emissions. Thus, using the environment index in this study has shown that the results of Shahbaz et al. (2013) and Charfeddine and Khediri (2016) for South Africa and the UAE, respectively, do not apply for Nigeria. The insignificant effect of capital investment and urbanization on environmental degradation measures in the model means these are not critical determinants of environmental changes in Nigeria. This might be attributed to the low level of industrial activity in the country. Because industrial activities in Nigeria are confined to a few states such as Lagos, Rivers, Kano, and Abuja, the rate of urbanization in this country is meagre and Nigeria has 
a large rural sector that is characterized by subsistence activities. This may explain why the urbanization rate is not significant in explaining environmental changes in the country.

\section{Conclusion and Recommendation}

In this study, we have shed light on the determinants of environmental quality in Nigeria, with a focus on the role of financial sector development. Using a time series analysis covering the period from 1981 to 2016, we analyzed several potential determinants of environmental quality, such as urbanization, per capita income, energy consumption, trade intensity, capital investment, and financial development. We also generated an environmental quality index from $\mathrm{CO}_{2}$ emissions and particulate emissions damage, using PCA. The study applied the ARDL bounds testing approach and used the data sourced from the World Development Indicators and Nigeria's Central Bank Statistical Bulletin. The long-run result confirms that income, financial development, energy consumption, and trade are significant in explaining environmental quality, whereas investment and urbanization are insignificant in the model during the period of study. We also confirmed the EKC proposition in Nigeria. Moreover, the causality analysis revealed that there is no feedback effect between the financial sector and the environment or between capital investment and environmental quality. There is, however,

unidirectional causality running from urbanization and income to the environment, and there is bidirectional causality between energy consumption and environmental degradation. We recommend that financial sector operators adequately screen investment proposals before committing funds to them to ensure efficient credit allocation to low carbon emitting firms. This will help to lower carbon emissions and make both the financial sector and capital investment drive environmental quality in the country. Also, because energy consumption significantly worsened environmental conditions, the Nigerian government should devote at least $5 \%$ of the annual budget to invest in renewable energy and increase its proportion of the energy supply mix. This will enhance the capacity of energy consumption to significantly improve environmental quality in Nigeria.

\section{References}

Abid, M. (2017). Does economic, financial and institutional developments matter for environmental quality? A comparative analysis of EU and MEA countries. Journal of Environmental Management, 188:183 - 194.

Adekunle, O., Salami, G., and Oluseyi, A. (2013). Impact of Financial Sector Development on 
the Nigerian Economic Growth. American Journal of Business and Management, 2(4):347356.

Aderibigbe, J. (2001). The role of the financial sector in poverty reduction. CBN Economic and Financial Review, 39 (3):1 - 19.

Al-mulali, U., Fereidouni, H. G., Lee, J. Y., and Sab, C. N. B. C. (2013). Exploring the relationship between urbanization, energy consumption, and CO2 emission in MENA countries. Renewable and Sustainable Energy Reviews, 23:107 - 112.

Al-mulali, U. and Sab, C. N. B. C. (2012). The impact of energy consumption and CO2 emission on the economic and financial development in 19 selected countries. Renewable and Sustainable Energy Reviews, 16(7):4365 - 4369.

Alam, A., Azam, M., Abdullah, A. B., Malik, I. A., Khan, A., Hamzah, T. A. A. T., Faridullah, Khan, M. M., Zahoor, H., and Zaman, K. (2015). Environmental quality indicators and financial development in Malaysia: unity in diversity. Environmental Science and Pollution Research, 22(11):8392-8404.

Alege, P. O. and Ogundipe, A. A. (2015). Environmental quality and economic growth in Nigeria: A fractional cointegration analysis. International Journal of Development and Sustainability, 2(2)(2):1 - 17 .

Andreoni, J. and Levinson, A. (2001). The simple analytics of the environmental Kuznets curve. Journal of Public Economics, 80(2):269 - 286.

Bekhet, H. A., Matar, A., and Yasmin, T. (2017). CO2 emissions, energy consumption, economic growth, and financial development in GCC countries: Dynamic simultaneous equation models. Renewable and Sustainable Energy Reviews, 70:117 - 132.

Boutabba, M. A. (2014). The impact of financial development, income, energy and trade on carbon emissions: Evidence from the Indian economy. Economic Modelling, 40:33 - 41.

Central Bank of Nigeria (2017). CBN Annual Report and Statistical Bulletin for the Year Ended 31st December. http://www.cbn.gov.ng/documents/statbulletin.asp. Accessed February 22, 2018.

Charfeddine, L., Al-Malk, A. Y., and Korbi, K. A. (2018). Is it possible to improve environmental quality without reducing economic growth: Evidence from the Qatar economy. Renewable and Sustainable Energy Reviews, 82:25 - 39. 
Charfeddine, L. and Khediri, K. B. (2016). Financial development and environmental quality in UAE: Cointegration with structural breaks. Renewable and Sustainable Energy Reviews, $55: 1322-1335$.

Copeland, B. R. and Taylor, M. S. (1994). North-South Trade and the Environment*. The Quarterly Journal of Economics, 109(3):755-787.

Dasgupta, S., Laplante, B., and Mamingi, N. (2001). Pollution and Capital Markets in Developing Countries. Journal of Environmental Economics and Management, 42(3):310 $-335$.

Dasgupta, S., Laplante, B., Wang, H., and Wheeler, D. (2002). Confronting the Environmental Kuznets Curve. Journal of Economic Perspectives, 16(1):147-168.

Eregha, P. B. and Mesagan, E. P. (2017). Energy consumption, oil price and macroeconomic performance in energy dependent African countries. Applied Econometrics, 46:74-89.

Frankel, J. A. and Rose, A. K. (2005). Is Trade Good or Bad for the Environment? Sorting Out the Causality. The Review of Economics and Statistics, 87(1):85-91.

Isola, W. and Mesagan, E. (2014). Impact of Oil Production on Human Condition in Nigeria. West African Journal of Monetary and Economic Integration, 14 (1):84 - 102.

Jalil, A. and Feridun, M. (2011). The impact of growth, energy and financial development on the environment in China: A cointegration analysis. Energy Economics, 33(2):284 - 291.

Javid, M. and Sharif, F. (2016). Environmental Kuznets curve and financial development in Pakistan. Renewable and Sustainable Energy Reviews, 54:406 - 414.

Kahouli, B. (2017). The short and long run causality relationship among economic growth, energy consumption and financial development: Evidence from South Mediterranean Countries (SMCs). Energy Economics, 68:19 - 30.

Karanfil, F. (2009). How many times again will we examine the energy-income nexus using a limited range of traditional econometric tools? Energy Policy, 37(4):1191 - 1194.

Khan, A., Saleem, N., and Fatima, S. (2018). Financial development, income inequality, and CO2 emissions in Asian countries using STIRPAT model. Environmental Science and Pollution Research, 25(7):6308-6319.

Levine, R. (1996). Foreign banks, financial development, and economic growth. International financial markets: Harmonization versus competition, 7:224 - 54 . 
Li, Z., Xu, N., and Yuan, J. (2015). New evidence on trade-environment linkage via air visibility. Economics Letters, 128:72 - 74 .

Mahalik, M. K., Babu, M. S., Loganathan, N., and Shahbaz, M. (2017). Does financial development intensify energy consumption in Saudi Arabia? Renewable and Sustainable Energy Reviews, 75:1022 - 1034 .

Maji, I., Habibullah, M., and Saari, M. (2017). Financial development and sectoral CO2 emissions in Malaysia. Environmental Science and Pollution Research, 24(8):7160-7176.

Mesagan, E., Isola, W., and Ajide, K. (2018). The capital investment channel of environmental improvement: evidence from BRICS. Environment, Development and Sustainability, $24: 1-22$.

Mesagan, E. P. (2015). Economic growth and carbon emission in Nigeria. The IUP Journal of Applied Economics, XIV(4):61-75.

Moghadam, H. E. and Dehbashi, V. (2018). The impact of financial development and trade on environmental quality in Iran. Empirical Economics, 54(4):1777-1799.

Nasreen, S., Anwar, S., and Ozturk, I. (2017). Financial stability, energy consumption and environmental quality: Evidence from South Asian economies. Renewable and Sustainable Energy Reviews, 67:1105 - 1122 .

Nwilo, P. C. and Badejo, O. T. (2006). Impacts and management of oil spill pollution along the Nigerian coastal areas. Administering Marine Spaces: International Issues, 119:1-15.

Omri, A., Daly, S., Rault, C., and Chaibi, A. (2015). Financial development, environmental quality, trade and economic growth: What causes what in MENA countries. Energy Economics, 48:242 - 252 .

Ozturk, I. and Acaravci, A. (2013). The long-run and causal analysis of energy, growth, openness and financial development on carbon emissions in Turkey. Energy Economics, $36: 262-267$.

Paul, S. and Bhattacharya, R. N. (2004). CO2 emission from energy use in India: a decomposition analysis. Energy Policy, 32(5):585 - 593.

Pesaran, M. H. and Shin, Y. (1998). An autoregressive distributed-lag modelling approach to cointegration analysis. Econometric Society Monographs, 31:371 - 413.

Pesaran, M. H., Shin, Y., and Smith, R. J. (2001). Bounds testing approaches to the analysis of level relationships. Journal of Applied Econometrics, 16(3):289-326. 
Sadorsky, P. (2011). Financial development and energy consumption in Central and Eastern European frontier economies. Energy Policy, 39(2):999 - 1006.

Sadorsky, P. (2014). The effect of urbanization on CO2 emissions in emerging economies. Energy Economics, 41:147 - 153.

Saidi, K. and Mbarek, M. B. (2017). The impact of income, trade, urbanization, and financial development on CO2 emissions in 19 emerging economies. Environmental Science and Pollution Research, 24(14):12748 - 12757.

Salahuddin, M., Alam, K., Ozturk, I., and Sohag, K. (2018). The effects of electricity consumption, economic growth, financial development and foreign direct investment on CO2 emissions in Kuwait. Renewable and Sustainable Energy Reviews, 81:2002 - 2010.

Shahbaz, M., Hoang, T. H. V., Mahalik, M. K., and Roubaud, D. (2017). Energy consumption, financial development and economic growth in India: New evidence from a nonlinear and asymmetric analysis. Energy Economics, 63:199 - 212.

Shahbaz, M., Hye, Q. M. A., Tiwari, A. K., and Leitão, N. C. (2013). Economic growth, energy consumption, financial development, international trade and CO2 emissions in Indonesia. Renewable and Sustainable Energy Reviews, 25:109 - 121.

Shahbaz, M., Sbia, R., Hamdi, H., and Ozturk, I. (2014). Economic growth, electricity consumption, urbanization and environmental degradation relationship in United Arab Emirates. Ecological Indicators, 45:622 - 631.

Solarin, S. A., Al-Mulali, U., Musah, I., and Ozturk, I. (2017). Investigating the pollution haven hypothesis in Ghana: An empirical investigation. Energy, 124:706 - 719.

Soytas, U., Sari, R., and Ewing, B. T. (2007). Energy consumption, income, and carbon emissions in the United States. Ecological Economics, 62(3):482 - 489.

Stern, D. I. (2004). The Rise and Fall of the Environmental Kuznets Curve. World Development, $32(8): 1419$ - 1439 .

World Bank (2016). New Data Reveals Uptick in Global Gas Flaring. http://www.worldbank.org/en/news/press-release/2016/12/12/new-data-reveals-uptickin-global-gas-flaring. Accessed July 11, 2018.

World Development Indicators (2017). The World Bank Databank. http://databank.worldbank.org/data/reports.aspx?source=world-development-indicators. Accessed February 10, 2017. 


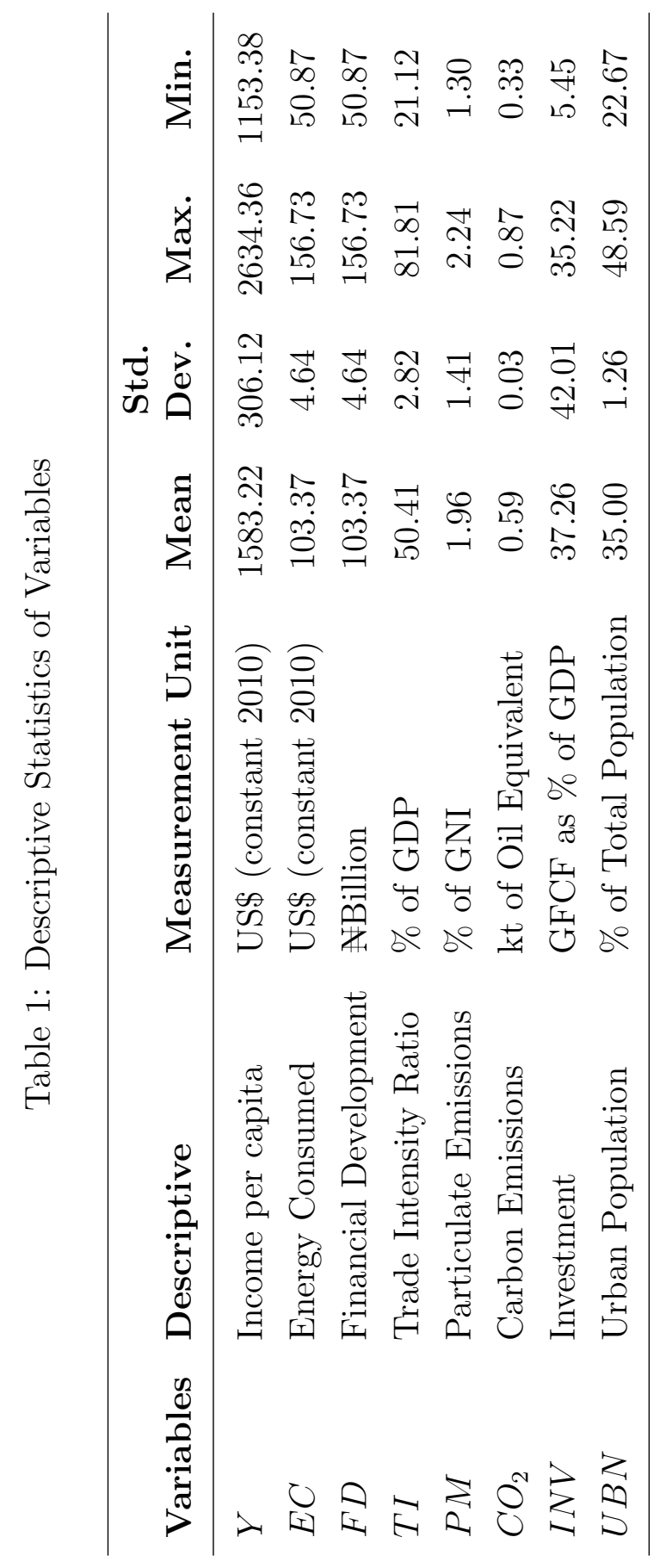


Table 2: Correlation Matrix of Regressors

\begin{tabular}{lcccccccc}
\hline & $Y$ & $C O_{2}$ & $P M$ & $I N V$ & $E C$ & $F D$ & $T I$ & $U B N$ \\
\hline$Y$ & 1 & & & & & & & \\
$C O_{2}$ & 0.214 & 1 & & & & & & \\
$P M$ & 0.023 & -0.492 & 1 & & & & & \\
$I N V$ & -0.342 & 0.417 & 0.142 & 1 & & & & \\
$E C$ & 0.491 & 0.380 & 0.282 & -0.352 & 1 & & & \\
$F D$ & -0.326 & 0.454 & -0.043 & 0.052 & -0.062 & 1 & & \\
$T I$ & 0.432 & 0.065 & 0.109 & 0.493 & 0.491 & -0.253 & 1 & \\
$U B N$ & 0.501 & 0.504 & -0.342 & 0.439 & 0.523 & 0.292 & 0.418 & 1 \\
\hline
\end{tabular}

Table 3: ADF Unit Root Tests for the Estimators

\begin{tabular}{lccccc}
\hline \multirow{2}{*}{ Variables } & \multicolumn{2}{c}{ Levels } & \multicolumn{2}{c}{ First Difference } & Stationarity \\
\cline { 2 - 5 } Variables & No Trend & Trend & No Trend & Trend & Status \\
\hline$Y$ & -0.324 & -0.403 & $-4.603^{* *}$ & $-5.078^{* *}$ & $I(1)$ \\
$T I$ & $-1.723^{* *}$ & -1.732 & $-5.023^{* *}$ & $-7.347^{* *}$ & $I(1)$ \\
$I N V$ & $-2.887^{*}$ & -2.406 & $-5.206^{* *}$ & $-5.0173^{* *}$ & $I(1)$ \\
$P M$ & -0.036 & -3.234 & $-6.267^{* *}$ & $-6.018^{* *}$ & $I(1)$ \\
$E C$ & 0.723 & -1.084 & $-4.492^{* *}$ & $-5.271^{* *}$ & $I(1)$ \\
$F D$ & $-1.372^{*}$ & $-2.481^{*}$ & $-4.881^{* *}$ & $-6.106^{* *}$ & $I(1)$ \\
$U B N$ & -3.204 & -2.126 & $-5.261^{* *}$ & $-5.528^{* *}$ & $I(1)$ \\
$C O_{2}$ & -0.935 & -1.058 & $-6.923^{* *}$ & $-7.037^{* *}$ & $I(1)$ \\
\hline
\end{tabular}




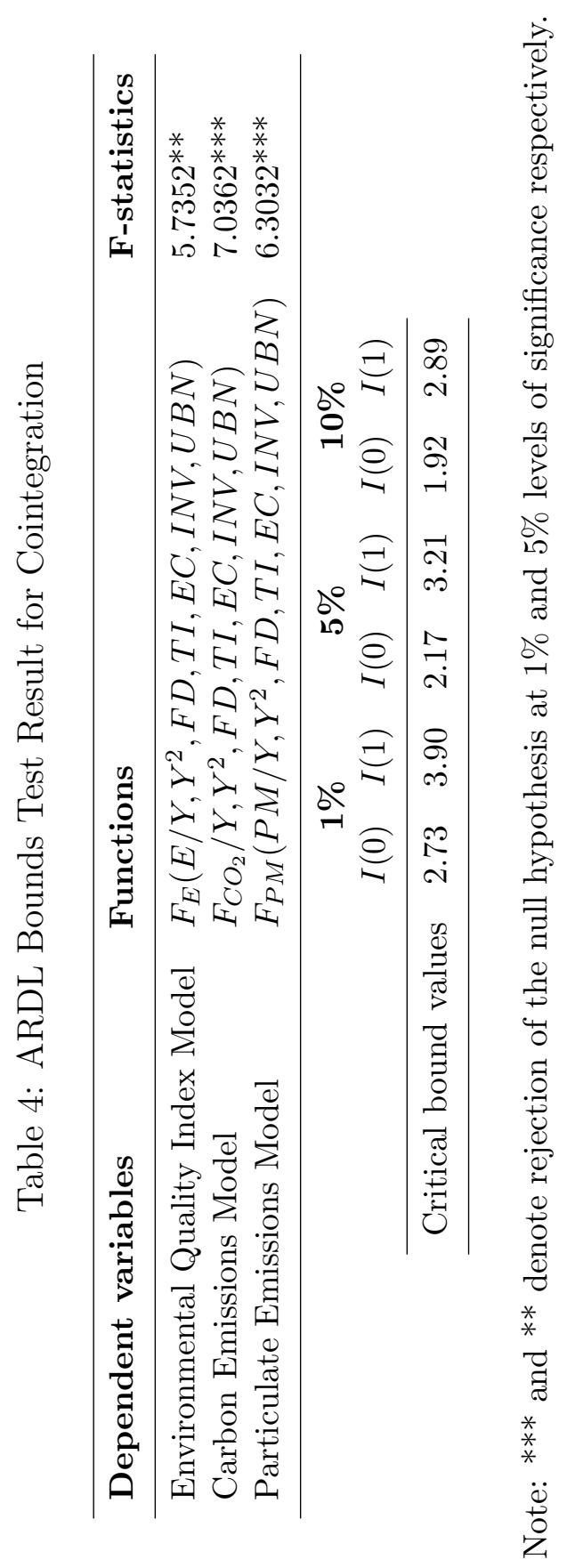


Table 5: Results of the Estimated ARDL Long-Run Coefficients

\begin{tabular}{lccc}
\hline \multirow{2}{*}{ Explanatory } & \multicolumn{3}{c}{ Dependent Variables } \\
\cline { 2 - 4 } & $\begin{array}{c}\text { Environmental } \\
\text { Degradation Index }\end{array}$ & $\begin{array}{c}\text { Carbon } \\
\text { Emissions }\end{array}$ & $\begin{array}{c}\text { Particulate } \\
\text { Emissions }\end{array}$ \\
\cline { 2 - 4 } & I & II & III \\
\hline Constant & $1.734^{* *}$ & -3.981 & 4.032 \\
& $(3.46)$ & $(2.80)$ & $(2.04)$ \\
& $0.175^{*}$ & $2.631^{* *}$ & $0.332^{*}$ \\
$Y^{2}$ & $(0.57)$ & $(0.62)$ & $(1.82)$ \\
& $-1.453^{* *}$ & $4.39^{*}$ & $-1.048^{* *}$ \\
$F D$ & $(0.36)$ & $(0.76)$ & $(0.29)$ \\
& $0.397^{* *}$ & $0.431^{*}$ & 0.621 \\
& $(0.44)$ & $(0.93)$ & $(0.39)$ \\
$T I$ & $4.937^{*}$ & $2.048^{* *}$ & $0.418^{*}$ \\
& $(0.29)$ & $(0.43)$ & $(0.152)$ \\
$I N V$ & $0.732^{* *}$ & $2.912^{*}$ & $-0.358^{*}$ \\
& $(0.12)$ & $(0.17)$ & $(0.34)$ \\
$U B N$ & 0.037 & 0.193 & $-0.045^{*}$ \\
& $(0.09)$ & $(0.29)$ & $(0.371)$ \\
& 2.835 & 1.374 & $1.834^{* *}$ \\
& $(2.21)$ & $(0.37)$ & $(0.72)$ \\
\hline
\end{tabular}

Note:**,*,() denote statistical significance at $1 \%$ and $5 \%$ critical levels, Stand, Error, respectively. 
Table 6: Models' Diagnostic and Stability Tests

\begin{tabular}{lccc}
\hline \multirow{2}{*}{ Test Statistics } & \multicolumn{3}{c}{ Dependent Variables } \\
\cline { 2 - 4 } & $\begin{array}{c}\text { Environmental } \\
\text { Degradation Index }\end{array}$ & $\begin{array}{c}\text { Carbon } \\
\text { Emissions }\end{array}$ & $\begin{array}{c}\text { Particulate } \\
\text { Emissions }\end{array}$ \\
\cline { 2 - 4 } Serial correlation & I & II & III \\
\hline Functional form & $(0.365$ & 5.921 & 6.403 \\
& 2.561 & $(0.023)$ & $(0.058)$ \\
Normality & $(0.126)$ & 3.052 & 1.203 \\
& 2.831 & $(0.062)$ & $(0.275)$ \\
Heteroskedasticity & $(0.261)$ & 1.046 & 3.925 \\
& 1.336 & $(0.303)$ & $(0.835)$ \\
CUSUM & $(0.273)$ & 2.837 & 0.289 \\
CUSUMSQ & Stable & $(0.193)$ & $(0.382)$ \\
ECT(-1) & Stable & Stable \\
& -1.782 & Stable & Stable \\
& $(0.000)^{* *}$ & -0.835 & -0.639 \\
& & $(0.001)^{* *}$ & $(0.000)^{* *}$ \\
\hline
\end{tabular}

Note: ${ }^{* *},()$ denote rejection of null hypothesis at $5 \%$ critical levels, probability values for the tests. 


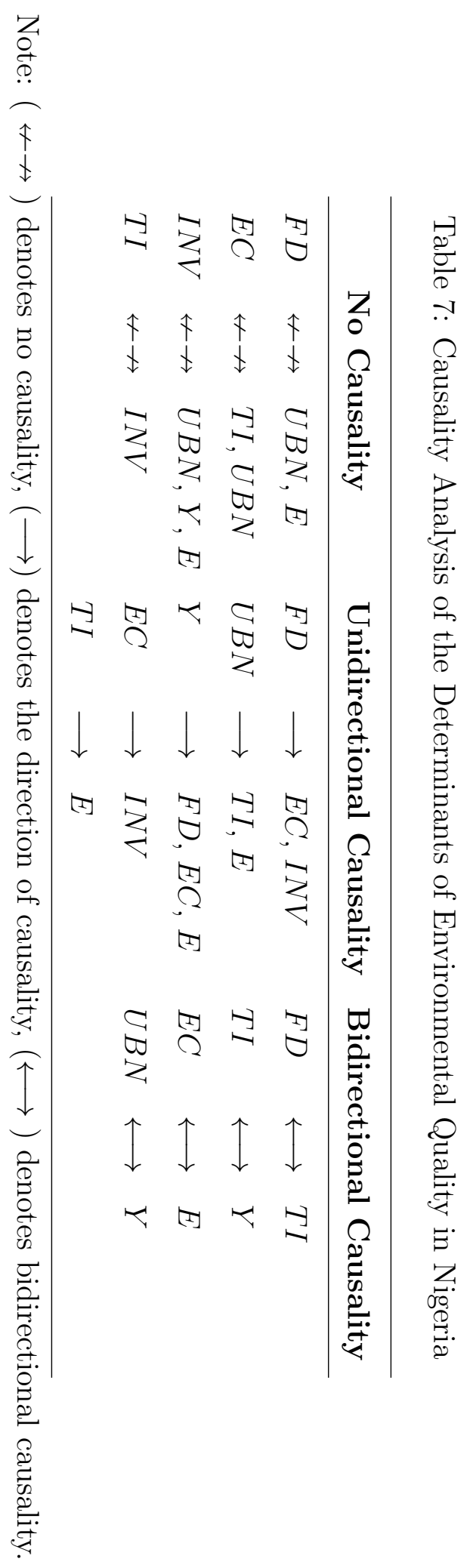

